\title{
PERAN PSIKOLOGI DALAM PENCAPAIAN STANDAR PENDIDIKAN NASIONAL
}

\author{
Gantina Komalasari \\ Program Studi Psikologi Fakultas Ilmu Pendidikan Universitas Negeri Jakarta \\ Email:
}

\begin{abstract}
Among inmates, there is also silent community of drug users. Banceuy prison is the special prison in the city of Bandung, for inmates related to drug use crime. Recent data has shown that there are a lot of IDUs among inmates, and the cases of HIV positive among those are in the range of 20-53\%. [(Banceuy-Bandung prison, 24\% (2002); (Indonesian HIV/AIDS Prevention Care Project (IHCP) and Indonesian Health Department, 2003)]. The Objective are to explore and understand the knowledge, perception and attitude of prison staffs regarding the program of reducing high risk behavior related to HIV among inmates. Method of data gathering is Focus Group Discussion, was collected from 42 out of 115 staffs and the analyze using qualitative approach. The conclusions is sometimes conflict between prison rules and prison staffs understanding, about handling the HIV/AIDS inmates creates uncertainty on implementing the policy (such as in the case of condom and MMT programs).
\end{abstract}

Key-words : Prison staff, IDU's, Inmates, HIV/AIDS

Merujuk pada laporan UNDP pada tanggal 27 November 2007 angka IPM atau Human Development Indeks Indonesia mengalami kenaikan menjadi 0.728 . Indonesia berada pada peringkat 108 sedunia dan masih di bawah Vietnam. Walaupun demikian bila ditelaah berdasarkan laporan Millennium Development Goals tahun 2008, tentang pencapaian tujuan kedua yaitu Mencapai Pendidikan Dasar Untuk Semua pada tahun 2015, diketahui bahwa untuk negara-negara di Asia Tenggara termasuk Indonesia berada pada kategori high enrolment, yang ditunjukkan dengan tingkat partisipasi di SD sebesar $94.7 \%$, namun angka kelulusan hanya 77\%, Di samping itu, persentase melek huruf penduduk usia 1524 tahun sebesar $99.4 \%$.

Sebagai negara besar yang sudah lama merdeka dan memiliki kekayaan alam yang melimpah, kondisi ini adalah sesuatu yang paradoks. Dengan segala potensi yang dimiliki, secara ideal semestinya Indonesia berada pada level yang tinggi dalam HDI. Keadaan inilah yang melatari keinginan pemerintah untuk memperbaiki kualitas SDM melalui pendidikan. Kebijakan yang dilahirkan untuk mendorong peningkatan pendidikan melalui pemberlakukan UU Sisdiknas No 20 tahun 2003 pasal 6 Setiap warga negara yang berusia tujuh sampai dengan lima belas tahun wajib mengikuti pendidikan dasar. Pasal 34 ayat 1 Setiap warga negara yang berusia 6 tahun dapat mengikuti program wajib belajar. Pasal 35 ayat 1 dan ayat 3 tentang standar nasional pendidikan yang menyatakan Standar nasional pendidikan terdiri atas standar isi, proses, kompetensi lulusan, tenaga kependidikan, sarana dan prasarana, pengelolaan, pembiayaan, dan penilaian pendidikan yang harus ditingkatkan secara berencana dan berkala. Pengembangan standar nasional pendidikan serta pemantauan dan pelaporan pencapaiannya secara nasional dilaksanakan oleh suatu badan standardisasi, penjaminan, dan pengendalian mutu pendidikan. Untuk menetapkan pencapaian kualifikasi lulusan secara nasional dilakukan melalui penilaian hasil belajar yang dilakukan oleh pemerintah yaitu melalui pelaksanaan UN yang obyektif, berkeadilan dan akuntabel, seperti diamanatkan oleh PP 19 tahun 2005 tentang standar nasional pendidikan pasal 66 ayat 1 dan 2. Di sini hasil ujian nasional digunakan sebagai salah satu pertimbangan untuk pemetaan mutu program dan/atau satuan pendidikan dan penentuan kelulusan peserta didik dari program dan/atau satuan pendidikan.

Ujian Nasional (UN) merupakan 
kebijakan yang telah ditetapkan oleh pemerintah (Permendiknas, nomor 34 tahun 2007). Secara umum ujian nasional diselenggarakan untuk meningkatkan kualitas Sumber Daya Manusia (SDM). Bercermin kepada negara lain, pendidikan menjadi penentu tinggi rendahnya standar kualitas manusia. Kualitas SDM yang tinggi menjadi modal bagi pembangunan nasional dan menjadi comparative advantage dalam dunia yang makin kompetitif.

Harapan tersebut dalam prakteknya memunculkan polemik di masyarakat. Pihak yang tidak setuju mengajukan berbagai argumentasi yang menyatakan bahwa UN tidak layak dilanjutkan karena memiliki berbagai kelemahan dan mengukur prestasi siswa secara tidak adil. Kondisi geografis Indonesia yang terdiri dari banyak pulau memberikan konsekuensi kepada keragaman standar mutu pendidikan setiap daerah. Dengan demikian UN menjadi ukuran yang tidak valid untuk diterapkan. Sementara pihak yang mendukung berusaha menjelaskan Ujian Nasional dari berbagai sudut positif berupa kualitas pendidikan yang semakin membaik.

Dalam pendidikan formal, hasil belajar harus menunjukkan adanya perubahan yang sifatnya positif sehingga pada akhirnya siwa akan mendapatkan keterampilan, kecakapan dan pengetahuan baru (Suryabrata,1998). Menurut Irwanto (1997), belajar merupakan proses perubahan dari belum mampu menjadi mampu dan terjadi dalam jangka waktu tertentu. Belajar akan menghasilkan perubahan-perubahan dalam diri seseorang. Untuk mengetahui sampai seberapa jauh perubahan yang terjadi, perlu adanya penilaian (Slameto,1988), sehingga seorang siswa yang mengikuti pendidikan selalu akan menghadapi evaluasi dari hasil belajarnya. Hasil dari proses belajar tersebut tercermin dalam prestasi belajar yang dapat diukur dari pencapaian standar kompetensi lulusan yang tertuang pada Peraturan Pemerintah Republik Indonesia Nomor 19 Tahun 2005 tentang Standar Nasional Pendidikan. Penyusunan KTSP oleh sekolah dimulai tahun ajaran 2006/2007 dengan mengacu pada Standar Isi dan Standar Kompetensi Lulusan untuk pendidikan dasar dan menengah sebagaimana yang diterbitkan melalui Peraturan Menteri Pendidikan Nasional masing-masing Nomor 22 Tahun 2006 dan Nomor 23 Tahun 2006, serta Panduan Pengembangan KTSP yang dikeluarkan oleh BSNP.

Pada prinsipnya, KTSP merupakan bagian yang tidak terpisahkan dari Standar Isi, namun pengembangannya diserahkan kepada sekolah agar sesuai dengan kebutuhan sekolah itu sendiri. KTSP terdiri dari tujuan pendidikan tingkat satuan pendidikan, struktur dan muatan kurikulum tingkat satuan pendidikan, kalender pendidikan, dan silabus.

Pelaksanaan KTSP mengacu pada Permendiknas Nomor 24 Tahun 2006 tentang Pelaksanaan Standar Isi dan Standar Kompetensi Lulusan. Sedangkan penjelasan mengenai kompetensi lulusan dalam standar nasional pendidikan Indonesia dijelaskan dalam Undang Undang Nomor 20 Tahun 2003 tentang Sistem Pendidikan Nasional (Sisdiknas). Hal tersebut lebih diperjelas lagi dalam PP Nomor 19 tahun 2005 Pasal 25 ayat 4 yang menyatakan bahwa kompetensi lulusan seharusnya mencakup tiga aspek, yaitu aspek sikap (afektif), pengetahuan (kognitif), dan keterampilan (psikomotorik).

Akan tetapi pada kenyataannya standar kelulusan siswa hanya didasarkan pada keberhasilan siswa mengikuti ujian nasional yang hanya mengukur satu aspek kompetensi kelulusan, yakni aspek kognitif. Dalam kaitannya dengan mutu pendidikan, UN hanya melakukan evaluasi terhadap peserta didik. Padahal, menurut pasal 57 ayat 2 UU Sisdiknas, mutu pendidikan seharusnya didasarkan pada evaluasi yang mencakup peserta didik, lembaga, dan program pendidikan. Dari penjelasan di atas, dapat disimpulkan bahwa ujian nasional digunakan sebagai standardisasi yang dilakukan pemerintah Indonesia untuk meningkatkan mutu pendidikan.

Selain itu keabsahan dari ujian nasional yang dianggap sebagai standar nasional pendidikan tersebut belum terukur secara kuantitatif. Hal ini dapat dilihat pada hasil penelitian Astrid Candrasari dkk tahun 2008 dengan judul Ujian Nasional: Dapatkah Menjadi Tolak Ukur Standar Nasional 
Pendidikan? (Hasil Kajian Ujian Nasional Bahasa Inggris pada Sekolah Menengah Pertama). Hasil penelitian menunjukkan bahwa (1) kurikulum dan ujian nasional yang digunakan sebagai salah satu standardisasi pendidikan nasional berjalan tidak harmonis. Kurikulum memberikan isyarat lain, dengan ditetapkan kompetensi-kompetensi dasar yang tidak mampu terpetakan dalam evaluasi secara nasional, yaitu UN. (2) Soal-soal UN mata pelajaran bahasa Inggris tingkat SMP/MTs tahun pelajaran 2006/2007 tidak tersebar merata baik secara aspek topik maupun aspek kognitif. Pada aspek topik, $100 \%$ soal-soal UN tersebut hanya mampu menjelaskan satu aspek saja, yaitu reading. Soal ujian bahasa Inggris pada mata pelajaran bahasa Inggris, dalam hal pemetaan topik, seharusnya memuat empat hal, yaitu mendengarkan, berbicara, membaca, dan menulis. Pada aspek kognitif, soal-soal UN tersebar dalam 3 aspek yang pertama yaitu recall, demonstrate, dan analyze, namun aspek evaluate dan generate tidak mampu tergambarkan pada soal-soal UN tersebut.

Selain itu berbagai kondisi tersebut menimbulkan pro-kontra terhadap ujian nasional, di mana kelompok kontra menyatakan bahwa pemberian nilai dalam ujian merupakan bentuk dehumanisasi pendidikan karena menimbulkan ketidakpercayaan di antara guru dan siswa. Ujian menjadi cara untuk membandingbandingkan kemampuan di antara siswa dan telah menyebabkan kecemasan dan menurunkan harga diri bagi mereka yang bernilai buruk (Arends, 2007). Mereka yang mendukung evaluasi sering mengutuk praktik-praktik pendidikan yang menekankan pengujian berbagai keterampilan dasar yang telah keluar dari konteks dan tujuan utama pendidikan sehingga mengakibatkan munculnya kompetensi yang berlebihan.

\section{GAMBARAN SITUASI}

Terlepas dari polemik mengenai kebijakan yang berjalan, penerapan Ujian Nasional telah menyebabkan munculnya beberapa masalah kepada pihak-pihak yang terlibat dalam pendidikan, yaitu siswa, orang tua siswa, guru, kepala sekolah hingga kepala dinas. Semua pihak yang terkait dengan pendidikan merasakan kekhawatiran ketika menghadapi UN. Siswa dan orang tua khawatir apabila tidak lulus UN. Tidak lulus merupakan sebuah bencana besar karena berkaitan dengan kehidupan masa depan (Kompas, 18 April 2009).

Sebagai ilustrasi, Murni siswa SMA Gotong Royong Yogyakarta dan Pawestari siswa SMAN I Sedayu Bantul berasal dari lingkungan keluarga tidak mampu, dan sangat menggantungkan harapan masa depan dirinya dan keluarganya pada perolehan ijazah SMA. Ijazah menjadi satu-satunya pintu masuk untuk mendapat pekerjaan yang diharapkan dapat mengubah kehidupan ekonomi keluarga. Akan tetapi karena berbagai keterbatasan sarana, prasarana dan sumber belajar yang dimiliki membuat mereka tidak lulus UN tahun 2010. Kondisi ini membuatnya muram, putus harapan, dan merasa mengecewakan keluarga (Kompas, 26 Mei 2010). Selain itu Angga Roudhatul siswa SMAN I, seorang siswa yang selama ini selalu berprestasi baik, gagal UN karena salah satu mata pelajaran yang diujikan nilainya berada di bawah rata-rata minimal kelulusan.

Kondisi ini memupuskan harapannya untuk melanjutkan pendidikan di UGM yang sudah menerimanya saat ujian seleksi masuk mandiri. Demikian juga dengan guru dan kepala sekolah yang khawatir apabila anak didiknya tidak lulus, sehingga dikatakan tidak berhasil. Bagi mereka standar kelulusan UN yang rendah dapat menurunkan kredibilitas mereka sebagai pendidik dan pejabat. Hal ini terlihat dari pengungkapan pendapat tentang kegagalan UN tahun ini. Sebagai ilustrasi angka kelulusan SMA/MA/SMK Daerah Istimewa Yogyakarta tahun ini 76,3\%, dari 39.938 siswa peserta UN, berarti mengalami penurunan sebesar $18.8 \%$ dari kelulusan tahun 2009.

Fakta ini menunjukkan posisi terendah dalam delapan tahun terakhir. Para pendidik mengungkapkan perasaan kecewa. Mereka mengatakan bahwa sisi persiapan sudah dilakukan berbagai upaya oleh sekolah, antara lain bimbingan belajar intensif, uji 
coba UN, bimbingan khusus dari guru mata pelajaran, les privat, dan bimbingan psikologis; tetapi hasilnya tidak memuaskan, bahkan Gubernur DIY mengungkapkan kecewa atas hasil UN tahun ini (Kompas, 26 Mei 2010).

Kondisi ini terjadi juga di Flores Timur NTT. Pada tahun 2010 tradisi lulus $100 \%$ tumbang. Kegagalan mempertahankan tradisi membuat keluarga besar SMA Seminari Pius 12 Kisol sebagai salah satu sekolah terbaik dan sejumlah pihak hingga alumni merasa terkejut, hampir tidak percaya dan tidak siap menerimanya karena ini merupakan sejarah baru sejak berdiri setengah abad lalu. Ini merupakan potret buram pendidikan NTT. Mereka menyatakan bahwa peristiwa ini menjadi refleksi untuk meningkatkan koordinasi antar komponen sekolah yakni siswa, guru, dan kepala sekolah (Kompas, 26 Mei 2010)

Berbagai kondisi ini menimbulkan berbagai pendapat tentang faktor penyebab kegagalan UN, antara lain karena koordinasi kurang baik antar warga sekolah, kurang berperannya dinas pendidikan daerah, pendidikan tidak diurus oleh orang-orang yang berkompeten di bidangnya, kurangnya komitmen para pelaku pendidikan terhadap pendidikan itu sendiri, sistem UN yang diskriminatif dan terlalu angkuh, di mana penentuan kelulusan siswa tanpa mempertimbangkan diversitas kondisi sekolah seperti guru, fasilitas pendukung, sumber belajar, dan sebagainya. Sementara ahli pendidikan Conny R. Semiawan (2010) menyoroti pentingnya kedudukan manusia sebagai makhluk individu dan makhluk sosial, sebagai dasar penetapan dan pelaksanaan suatu kebijakan Negara khususnya dalam konteks pendidikan.

Manusia sebagai makhluk individu lahir sebagai pribadi yang unik, yang memiliki faktor genetis yang sangat berbeda dan tidak memiliki kesamaan dengan manusia lain maupun makhluk hidup lainnya di dunia. Selain ia juga memiliki keunikan sifat, potensi, dan bakatnya. Sebagai mahkluk individu, ia tumbuh kembang memiliki ambisi dan cita-cita, yang disebut Piaget sebagai a self generating trend. Walaupun demikian manusia juga merupakan makhluk sosial yang menjadi bagian dari lingkungannya, sehingga dituntut untuk mampu menyesuaikan diri dengan berbagai tuntutan yang ditetapkan lingkungan di mana ia berada. Manusia sebagai makhluk sosial harus dapat bertahan (sustain) dalam masyarakat di mana ia hidup (self sustaining). Namun persamaan yang dimiliki tidak berarti kita dibenarkan untuk bisa mengabaikan perbedaan manusia sebagai individu yang unik.

Pada konteks sistem pendidikan di Indonesia yang menyelenggarakan Ujian Nasional (UN), Indonesia sebagai negara seribu pulau dari Sabang sampai Merauke, memiliki kondisi pendidikan yang sangat heterogen, disertai budaya, dan peradaban yang beragam. Pemerintah sebagai penyelenggara UN harus memiliki tanggung jawab etis untuk mengadakan penilaian yang dapat dibenarkan/justified (assessment responsibility). Penetapan kriteria atau standar nasional yang juga memperhatikan standar keragaman kondisi daerah, sehingga kebijakan yang diterapkan tidak saja memperhatikan kesamaan manusia sebagai makhluk sosial, tetapi juga harus tetap memperhatikan hak keunikan manusia sebagai individu. Selain itu penghargaan dan perhatian kepada pemenuhan hak manusia sebagai makhluk individual yang unik, juga diamanatkan dalam pembukaan UUD 1945 Pasal 28 B ayat 2 (Amandemen UUD 1945) bahwa setiap anak berhak atas kelangsungan hidup, tumbuh dan berkembang serta berhak atas perlindungan dari kekerasan dan diskriminasi. Kemudian pada Pasal 28 C Ayat 2 (Amandemen UUD 1945) disebutkan bahwa setiap anak berhak mengembangkan diri melalui pemenuhan kebutuhan dasarnya, berhak mendapatkan pendidikan dan memperoleh manfaat dari ilmu pengetahuan dan teknologi, seni dan budaya, demi meningkatkan kualitas hidupnya dan demi kesejahteraan umat manusia.

Senada dengan itu, juga diperkuat dalam UU Perlindungan Anak No 23 tahun 2002 Pasal 9 Ayat 1, yang menyebutkan bahwa setiap anak berhak memperoleh pendidikan dan pengajaran dalam rangka pengembangan pribadinya dan tingkat 
kecerdasannya sesuai minat dan bakatnya. Menurut Conny Semiawan (2010), Batas Kelulusan Ujian Nasional yang ditetapkan melalui penetapan Standard Score dalam ujian nasional yang mengacu pada standar mutlak nilai kelulusan tingkat pendidikan tertentu dengan menilai apa yang seharusnya diperoleh sebagai pengetahuan peserta didik dengan nilai 5.5 yang disebut criterion referenced assement. Hal ini kurang menghiraukan apa yang diperoleh sebagai hasil belajar individu, sekolah, atau kondisi daerah tertentu, yang disebut learner. Bila kita ingin mengukur hasil belajar siswa (the learner), maka cara tujuan, sifat ataupun standarnya biasa digunakan rata-rata sebagai norma (norm referenced assessment).

Pendapat lain menyatakan bahwa UN hanya bermanfaat sebagai salah satu instrumen penilaian kinerja pemebelajaran nasional, tetapi tidak adil untuk menjadi instrumen penentu kelulusan siswa. UN hanya mengukur hasil dan tidak mengukur proses. Karenanya, UN tidak dapat dibandingkan tingkat kelulusan satu daerah dengan daerah lain, misalnya antara DKI Jakarta dengan NTT.

PERAN PSIKOLOGI DALAM

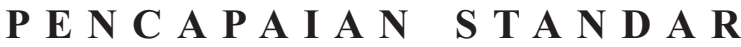
PENDIDIKAN NASIONAL

Berbagai kondisi yang telah dipaparkan sebelumnya, memposisikan pelaksanaan UN sebagai suatu keadaan yang menekan atau dianggap sebagai sumber stres oleh siswa, orang tua, guru, kepala sekolah, kepala dinas pendidikan, serta berbagai pihak terkait.

Penilaian terhadap suatu keadaan stres yang dihadapi dalam hal ini UN, sangat dipengaruhi oleh persepsi individu atau penilaian kognitif (cognitive appraisal) pada situasi atau stimulus sebagai potensi yang berbahaya atau merugikan. Penilaian terhadap keadaan ataupun rangsang yang dianggap mengancam dalam konteks ini ujian nasional, juga dipengaruhi sikap, pikiran-pikiran, kemampuan dan pengalaman sebagai hasil belajar di masa lalu dan ditentukan juga oleh kecenderungan pribadi seseorang, yaitu anxiety trait atau kecemasan dasarnya (Spielberger, 1979).
Oleh karenanya, apabila pada sebagian orang atas dasar sikap, pikiran, kemampuan, pertimbangan, dan pengalamannya menganggap UN sebagai situasi yang berpotensi merugikan, membahayakan, atau mengancam dirinya, maka akan muncul yang disebut kecemasan. Akan tetapi apabila pada sebagian lainnya ujian nasional dianggap sebagai suatu proses evaluasi yang sudah seharusnya terjadi pada setiap akhir suatu proses pendidikan formal, maka tidak akan menimbulkan kecemasan (Spielberger, 1979). Intensitas kecemasan sesaat yang tergugah menurut Hull (Hall dan Lindzey, 1981) sebanding dengan besarnya ancaman yang dihayati dan berlangsung terus tidaknya pengahayatan itu tergantung lamanya kehadiran rangsang dan pengalamannya menghadapi rangsang serupa di masa lalu atau bila memakai istilah Hull-Spence, kekuatan hubungan antara rangsang tertentu dengan respon tertentu disebut habit strength.

Menurut Gale Encyclopedia of Psychology (2001), kecemasan adalah ketidaknyamanan emosi yang dipicu oleh antisipasi kejadian yang akan datang (anticipation of future events), ingatan kejadian masa lalu (memories of past events) atau renungan mengenai diri sendiri (ruminations about the self), kecemasan distimulasi oleh bayangan bahaya atau bahaya nyata, dalam kondisi ujian penyebab kecemasan adalah antisipasi kejadian yang akan datang berupa menghadapi ketidaklulusan. Saat dihadapkan pada situasi yang dirasakan mengancam, dalam hal ini cemas terhadap kegagalan saat menghadapi $\mathrm{UN}$, biasanya individu akan menggugah upaya-upaya untuk mengatasinya, mengurangi, atau menghilangkan perasaan terancam atau kecemasan sesaat, karena pada dasarnya setiap individu mengharapkan berada pada keadaan homeostatis atau keseimbangan. Akibatnya, seseorang akan meningkatkan aktivitas kognisi, motorik, atau mekanisme pertahanan dirinya sehingga dapat memberi umpan balik bagi individu dalam menilai ujian nasional.

Situasi yang dirasakan mengancam disebut sebagai stressor, atau dengan perkataan lain sebagai situasi yang memiliki 
karakteristik objektif dengan derajat bahaya fisik dan psikologis. Ancaman atau situasi mengancam didapat sebagai hasil persepsi individu atau penilaian kognitif (cognitive appraisal) pada situasi atau stimulus sebagai potensi yang berbahaya atau merugikan. Penilaian terhadap keadaan ataupun rangsang yang dianggap mengancam dipengaruhi juga oleh sikap, pikiran-pikiran, perasaan, kemampuan dan pengalaman sebagai hasil belajar di masa lalu saat menghadapi situasi yang sejenis dan tentu saja oleh kecenderungan A-Trait atau kecemasan dasarnya setiap individu.

Proses di mana seseorang individu melihat situasi stres sebagai sesuatu yang mengancam hingga menimbulkan reaksi cemas, menunjukkan keadaan stres (Spielberger, 1979). Pada saat seseorang mengakui atau menginterpretasikan suatu situasi sebagai potensi yang merugikan, membahayakan atau mengancam dirinya, maka akan muncul kecemasan sesaat (Spielberger, 1979). Perasaan cemas terhadap kegagalan saat menghadapi UN dalam intensitas rendah sampai menengah akan menimbulkan nervous, tegang dan takut pada apa yang akan terjadi. Pada tingkat sedang sampai tinggi direfleksikan dalam keadaan gelisah, sukar bernafas, gemetar, berkeringat, otot menjadi tegang. Sedangkan pada tingkat yang tingggi kadang disertai tingkah laku panik (Spielberger, 1979).

Berbagai penelitian menunjukkan bahwa kecemasan secara konsisten memiliki efek negatif terhadap prestasi akademik siswa (Covington, 1992; Zeidner, 1998). Kecemasan memberikan efek samping motorik dan viseral dan mempengaruhi proses berpikir, persepsi dan belajar. Kecemasan cenderung menghasilkan kebingungan dan distorsi persepsi, tidak hanya pada ruang dan waktu tetapi pada orang dan arti peristiwa. Distorsi tersebut dapat mengganggu belajar dengan menurunkan kemampuan memusatkan perhatian, menurunkan daya ingat, dan mengganggu kemampuan dalam membuat asosiasi (Kaplan \& Saddock, 1997).

Kecemasan dengan intensitas yang wajar memiliki nilai positif sebagai motivasi, karena akan menyebabkan individu menjadi lebih waspada dan mendorong upaya yang lebih keras untuk mencapai apa yang diharapkan. Sementara dalam intensitas yang sangat kuat akan berdampak negatif karena mengganggu kondisi fisik dan psikis individu yang bersangkutan. Hal ini sejalan dengan pendapat Sieber et.al. (1977) yang mengungkapkan bahwa kecemasan dianggap sebagai salah satu faktor penghambat dalam belajar yang dapat mengganggu kinerja fungsi-fungsi kognitif seseorang, seperti kesulitan untuk berkonsentrasi, mengingat, pembentukan konsep dan pemecahan masalah. Pada kondisi yang kronis, gejala kecemasan dapat berbentuk gangguan fisik (somatik), seperti gangguan pada saluran pencernaan, sering buang air, sakit kepala, gangguan jantung, sesak di dada, gemetaran bahkan pingsan.

Bila dikaitkan dalam konteks pembelajaran, kecemasan akan memberikan berbagai implikasi kepada orang yang mengalaminya berupa gangguan kognitif (Covington, 1992; Zeidner, 1998), gangguan emosi (Liebert \& Morris, 1967) dan yang mungkin akan mengarah kepada gangguan mental (Mazzone dkk, 2007)

Efek negatif kecemasan dalam ujian berimplikasi terhadap prestasi akademik siswa (Covington, 1992; Zeidner, 1998). Bahkan menurut Mazzone dkk (2007), kecemasan menyebabkan prestasi belajar rendah dan kegagalan belajar dan dapat mengarah kepada gangguan mental. Sedangkan bentuk reaksi negatif terhadap kecemasan dalam situasi tes berupa gangguan kekhawatiran kognitif dan gangguan respon emosional lain (Liebert \& Morris, 1967). Kekhawatiran kognitif terdiri dari pikiran negatif terhadap kemampuan sendiri untuk menghadapi ujian, misalnya ia akan berpikir " saya pasti gagal, saya pasti tidak bisa mengisinya dengan benar". Kondisi ini akan mengganggu anak untuk dapat memunculkan kemampuan yang sebenarnya pada saat menghadapi ujian. Kegelisahan pikiran ini akan terus muncul dalam pikiran anak selama ujian berlangsung bahkan ketika ujian telah selesai berlalu (Bandura, 1986). Gangguan emosional juga akan terefleksi dalam bentuk gangguan 
pencernaan, seperti diare, mulas-mulas dan pada akhirnya akan berpengaruh terhadap kinerja Zeidner(1998).

Dari asepek kognitif, kecemasan akan mengganggu setiap fase dalam proses pengolahan kognitif terutama dalam fase perencanaan dan encoding. Seseorang yang memiliki tingkat kecemasan yang tinggi akan mengalami kesulitan untuk menerima dan melakukan encoding informasi dengan tepat. Dapat dikatakan bahwa mereka akan kehilangan konsentrasi dan kesulitan untuk menggunakan memorinya dengan efisien. Penggunaan memori hanya dapat digunakan untuk proses yang bersifat sangat superfisial tetapi kurang optimal untuk memproses yang lebih mendalam serta masalah yang memerlukan proses metakognitif dalam pembelajaran (Zeidner,1998). Dengan demikian tidak lah aneh bahwa gangguan proses kognitif dan gangguan pengaturan diri (self regulation) akan menyebabkan prestasi belajar yang rendah.

Berdasarkan uraian sebelumnya tampak kecemasan yang muncul dalam menghadapi UN, tidak hanya dialami oleh siswa tetapi juga pihak-pihak lain yang terlibat, termasuk orang tua dan pihak sekolah. Untuk mengatasi kecemasan siswa berupaya belajar giat, banyak berlatih pemecahan soal ujian nasional tahun-tahun sebelumnya, ikut berbagai bimbingan belajar, atau siswa menghindar untuk ikut ujian nasional karena merasa sukar atau tidak yakin untuk berhasil, orang tua berusaha keras mencari lembaga bimbingan belajar yang alih-alih membantu anak dan menjamin bahwa anaknya akan lulus. Sementara pihak sekolah melakukan upaya untuk mengatasi kecemasan dimanifestasikan dalam bentuk memberikan pengayaan pada siswa dengan memberi jam tambahan bimbingan oleh guru saat sepulang sekolah, bekerjasama dengan lembaga bimbingan belajar, melakukan kegiatan berdoa bersama, bahkan dapat memunculkan perilaku menyimpang, misalnya melakukan kecurangan, berusaha membocorkan soal ujian demi nama baik sekolah, pemberian kunci jawaban sebelum ujian berlangsung, atau bahkan lembar jawaban yang sudah diisi terlebih dahulu dengan harapan agar siswa mereka lulus
(Kompas, 20 Januari 2010). Kecurangan yang dilakukan pihak sekolah secara sadar akan mendistorsi tujuan pendidikan dan menafikan nilai-nilai moral luhur anak bangsa.

Semua perilaku tersebut dilakukan sebagai upaya untuk mengantarkan siswa peserta UN dapat lulus dan mencapai target kelulusan yang diharapkan meskipun hasil tersebut tidak mencerminkan kemampuan siswa yang sebenarnya. Berdasarkan uraian sebelumnya, dapat disimpulkan upayaupaya untuk mengatasi kecemasan dapat dilakukan melalui tiga cara, yaitu menghindari sumber bahaya, menghadapi sumber bahaya, dan memodifikasi situasi bahaya/mengancam melalui pertahanan diri (Spielberger, 1979).

Merujuk pada berbagai paparan sebelumnya mengenai berbagai dampak fisik, psikologis, dan sosial pada individu yang mengalami kecemasan menghadapi ujian nasional dan mengingat kecemasan merupakan proses psikis yang sifatnya tidak tampak di permukaan, untuk menentukan apakah seseorang siswa mengalami kecemasan atau tidak, diperlukan penelaahan yang seksama, dengan berusaha mengenali simptom atau gejala-gejalanya, beserta faktor-faktor yang melatarbelakangi dan mempengaruhinya. Kendati demikian, perlu dicatat bahwa gejala-gejala kecemasan yang bisa diamati di permukaan hanyalah sebagian kecil saja dari masalah yang sesungguhnya, ibarat gunung es di lautan, yang apabila diselami lebih dalam mungkin akan ditemukan persoalan-persoalan yang jauh lebih kompleks.

Oleh karena itu, diperlukan peran psikologi dalam mendorong upaya peningkatan pencapaian standar pendidikan nasional dan pencapaian standar kualifikasi sumber daya manusia Indonesia yang berkualitas agar dapat sejajar dengan negaranegara maju dan mampu menempati posisi yang dapat diperhitungkan secara global. Usaha tersebut dilakukan melalui pelaksanaan berbagai kajian ilmiah menggunakan metode Research and Development Models dengan menggunakan mixed methods research design yang merupakan suatu prosedur untuk 
mengumpulkan, menganalisis dan "mencampur" metode penelitian kuantitatif dan kualitatif dalam satu kajian untuk memahami sebuah masalah penelitian (Creswell, 2008), mengenai kecemasan menghadapi ujian nasional, berbagai faktor penyebab kecemasan siswa, orang tua, guru, kepala sekolah, dan dinas pendidikan dalam menghadapi ujian nasional, berbagai perilaku yang muncul akibat kecemasan, dan upaya-upaya yang dilakukan mereka untuk mengatasi kecemasan menghadapi ujian nasional.

Hasil kajian ilmiah dapat digunakan sebagai dasar pengembangan model intervensi psikologis untuk mempersiapkan individu atau kelompok individu mampu mengatasi kecemasan saat menghadapi ujian nasional dan mampu menerima kegagalan ujian nasional secara positif, sehingga mereka dapat menampilkan seluruh potensi yang dimiliki secara optimal dan mampu mencapai standar nasional kualifikasi lulusan. Selain itu secara lebih makro, bila dikaitkan dengan tingkat capaian posisi HDI dan pencapaian target MDGS Indonesia saat ini, perlu dilakukan upaya intervensi psikolologis yang terencana dan terprogram terhadap kondisi cemas yang melanda sebagian besar siswa pada satuan pendidikan dasar dan menengah di seluruh Indonesia. Karena bila tidak dilakukan, sukar diharapkan pada tahun 2015 Indonesia memiliki posisi HDI yang dapat diperhitungkan di tingkat Asia maupun tingkat dunia. Sekaligus akan sukar diharapkan sumber daya manusia Indonesia mampu berkompetisi pada tatanan global.

\section{DATAR PUSTAKA}

Arends. R.I.2007. Learning To Teach (terj.) edisi ketujuh. Yogyakarta: Pustaka pelajar

Anxiety Affect A Person's Mental Health. Anima, Indonesian Psychological Journal, 18 (45) : 319-325.

Borg, W.R., Gall, J.P., Gall, M.D 2003. Educational Research An Introduction. Boston: Pearson
Education, Inc.

Chaplin, J. P.2002. Kamus Lengkap Psikologi. Penerjemah Kartini Kartono. Jakarta: Raja Grafindo Persada

Creswell, J.W. 2008. Educational Research Planning, Conducting, and Evaluating Quantitative and Qualitative Research. New Jersey :Pearson Educatin.Inc

Candrasari. A.2008. Ujian Nasional: Dapatkah Menjadi Tolak Ukur Standar Nasional Pendidikan? (Hasil Kajian Ujian Nasional Bahasa Inggris Pada Sekolah Menengah Pertama). Jakarta : Putera Sampoerna Foundation

Hall. C.S. 2000. Libido Kekuasaan Sigmun Freud. Penerjemah, S. Tasrif. Yogyakarta: Karawang

Hall C.S. \& Lindzey 1981. Theories of Personality. Third edition. New York: John Wiley \& Sons

Kompas. 18 April 2009. Harap-harap Cemas Hadapi UN

Kompas. (20 Januari 2010). Kecurangan Ujian Nasional Diidentifikasi

Kompas. (26 Mei 2010). Sekolah Unggulan Pun Melorot

Kompas. (26 Mei 2010). Perkabungan dari DI Yogyakarta

Kompas. (26 Mei 2010). Angan-angan Patah Bersama Ijazah

Keputusan Badan Standar Nasional Pendidikan Nomor 0023/SkPos/Bsnp/Xii/2009 Tentang Prosedur Operasi Standar (Pos) Ujian Nasional Sekolah Menengah Atas Madrasah Aliyah (SMA/MA) Tahun Pelajaran $2009 / 2010$ 
Lazarus, R. S. 1976. Pattern Of Adjusment and Human Efectivenees. Kogakusha: McGraw Hill Book Compay

Mazzone, L. Ducci F, Scoto1, M. C. Passaniti1, E. D'Arrigo1 V. G. and Vitiello B. 2007. The Role of Anxiety Symptoms in School Performance in A Community Sample of Children and Adolescents. BMC Public Health $7: 347$.

McCroskey. 1984. The Communication Apprehension Perspective. Avaliable:

Olfson, M., dkk. 2000. Barriers to the Treatment of Social Anxiety. Am J Psychiatry, 1(57):521-527.

Peraturan Pemerintah nomor 19 Tahun 2005 Tentang Standar Nasional Pendidikan

Permendiknas Nomor 24 Tahun 2006 tentang Pelaksanaan Standar Isi dan Standar Kompetensi Lulusan

Strickland, B.(ed) 2001. The Gale Encyclopedia of Psychology, second edition. Detroit. Gale group

Slavin R.E. 2008. Psikologi Pendidikan Teori dan Praktek, edisi kedelapan. Jakarta: Indeks.

Semiawan, C. 2010. Ujian Nasional: Akar Masalah Dan Solusinya, (makalah ilmiah). Jakarta: Universitas Negeri Jakarta.

Sugiyono. 1994. Metode Penelitian Administrasi, Bandung: ALFABETA

Sugiyono. 2006. Metode Penelitian Pendidikan (Pendekatan Kuantitatif, Kualitatif dan $R \& D$ ). Bandung:Alfabete
Spielberger 1966. Anxiety and Behavior, New York : Academic Press

Spielberger 1972. Curent Trends in Theory and Reasearch on Anxiety. Vol I. New York : Academic Press

Spielberger 1979. Understanding Stress and Anxiety, London : Harper \& Row Publisher

Teichman, Y. 1974. Predisposition for Anxiety and Affiliation. Journal of Personality and Social Psychology 29 (3), 405-410.

Undang-Undang Sistim Pendidikan Nasional No. 20 Tahun 2003

UNDP, 2008. Laporan MDGs "Mari Kita Suarakan MDGs"

Vaughan, G. M \& Hogg, M.A. 2005. Introduction to Social Psychology, $4^{\text {th }}$ edition. Australia : Pearson Prentice Hall.

Waspada Online, 28 January 2010 : Siswa Medan'cemas' hadapi UN

\section{Internet}

www.as.wvu.edu/bpatters/isc3.htm (26 Jan1998)

http://disdikdki.net

http://tao.infoproduk.com/indeks. php? $\mathrm{p}=97 \#$ moore -97

http://www.mizan.com/portal/tem plate/BacaResensi/Resensiid/543

http://www.Kompas.com/Kesehat an/news/0302/28/020443.htmPeng embangan strategi instruksional 